\title{
Analysis of Major-setting Leading Role for Vocational Education
}

\author{
Qi Xuan \\ Institute of Education Economics and Administration \\ University of Science and Technology Beijing \\ Beijing,China \\ 15810801000@139.com
}

\begin{abstract}
Economical development is upgrading from-labor intensive to skill-intensive. In transformation period, the reasonable major setting determines career development of laborers to some extent, and similarly determines the future development of vocational education. It is of importance for the leading role of major setting for vocational education development.
\end{abstract} skills

Keywords- Major setting; vocational education; technical

The vocational education is defined in broad and narrow senses. In the broad sense, the vocational education refers to an activity of teaching technical knowledge and skills in labor and life by teaching personally and orally, practicing hand-me-down and training an apprentice by a master. In a narrow sense, the vocational school means an activity of teaching technical knowledge and professional skills purposefully and organizationally. Generally speaking, our study focuses on the concept of vocational education in a narrow sense. The studies of vocational education include macroscopic and microcosmic fields. In the macroscopic aspect, the study on the vocational education mainly includes vocational system, law of development, and its connotation and denotation; the study in microscopic field mainly deals with the contents for vocational education, including major setting, course setting, teachers and teaching, and ideological and moral education. Studying relation between major setting and vocational education is to highlight the importance of major setting in vocational education development, and to make the major setting of vocational education more reasonable.

\section{RELATION OF MAJOR SETTING AND VOCATIONAL EDUCATION}

\section{A. major is a carrier}

Reasonable major setting determines development level of vocational education. Firstly, the major is a carrier where the vocational education comes into play; the vocational education is available by education and teaching of majors. Therefore, the major setting carries contents, method and assessment criterion of implementation of vocational education.

\section{B. vocational education is a platform}

Vocational education is a platform for major setting. The vocational education is just like a stage, and the major setting is the dramaturgic program. In the macroscopic ordination of vocational education, the vocational setting has a real development "market" and favorable position. However, their relation is not absolute, and they can are converted mutually as carriers and platforms to satisfy their own requirements. Of course, they are regarded as a relation of form and content, that is, the former is vocational education, and the latter is the major setting.

\section{STUDY OF INFLUENCING FACTORS FOR MAJOR SETTING}

\section{A. the law of economical and social development}

From development of vocational education, the influencing factors for major setting mainly include three aspects: Firstly, the law of economical and social development is the macroscopic basis for major setting. Any professional talents are cultivated to serve the development of economic society, but merely their concrete posts and roles are different.

\section{B.the requirement of industrial development}

Secondly, reasonable major setting is a criterion to satisfy the requirement of industrial development. The development of industries needs the support of professional talents. The more quickly an industry develops, the more contribution it makes, and the more professional talents it needs, so that major setting is more reasonable in continuous improvement.

\section{C. the demands of diversified markets}

Thirdly, paying attention to the demands of diversified markets for major setting. In a broad sense, a state is a big market. It is diverse for demands of products or commodities and talents who are engaged in industries based on diversified demands. For this reason, major setting is diversified.

\section{ANALYSIS ON THE LEADING ROLE OF MAJOR SETTING TO VOCATIONAL EDUCATION DEVELOPMENT}

The major setting is a core carrier in the development of vocational education. The reasonable major setting determines status, characteristics and vitality of development of a vocational school. The competent 
departments of vocational education or vocation school itself can develop for a long term adhering to a most advanced idea aiming at the situation of international and national economical and social development.

\section{A. Role of Summary and promotion}

Any major setting is established on the basis of studies on economical and social development, especially for demands of industries and market development closely related to it. There are the following reasons.

Firstly, the major setting is the specific reflection of industrial development. Any major is set for cultivation of skilled talents for some industry, so before setting, we should study related industries, especially for summary of faults and results in the past and current development, in order to further improve the major setting in the future education and teaching;

Secondly, the major setting is a result of summary in practice of vocational education. The vocational education and teaching is an intermediate link of "coming from the practice then to the practice", and directly determines the future vocational development. Thus, the meticulous study should be done on the development law of technical skills in this industry, especially to find out disadvantages and advantages of the practical teaching operation and to add teaching contents to education and teaching. By this way, it makes for students' fast adaptation for the future job, and avoiding similar fault and mistakes to reduce unnecessary loss.

\section{B. Role of prospective study}

Substantially, the major setting is a theoretical discussion, that is, the major setting can play a prospective role in industry to some extent by studying the possibility of vocational technical development. In that way, what content should be discussed theoretically?

On one hand, it is a discussion on economic development situation. Any major is a detail in economical and social development, and can be realized by some specific post. Though the economic development situation is macroscopic, it can directly reflect application prospect of the technical skills for the major. Only when the major setting keeps a foothold potential field, students' ambitious expectation can be realized possibly, and the vigorous vitality of a vocational school can be made.

On the other hand, it is a discussion of vocational technical skills. Any school or competent department neither set a major, which is useless or out of practice, to social and economical development without destination, nor set a major with a low technical content. It should often make sure that students can master the independent technology by setting relatively comprehensive majors, and they realize their creative value by setting some majors. Thus, Great efforts should be made in technical skills, so that the virtuous circle of economic society can be promoted with cultivation of skilled talents in these majors.

\section{Role of innovation and breakthrough of technical skills}

The major for vocational education is targeted to cultivate the practical talents for the purpose of the industrial development directly. These people are front-line workers, and they should make different breakthroughs in practical work to realize their own value and contribution.

The first thing is the breakthrough of technical skills, that is, the so-called knowledge starts with practice. These talents who have accepted vocational education and mastered systematical professional knowledge can improve their current statuses of work more or less by accumulation of experience and summary of lessons in the long-term work.

The second thing is the breakthrough of theoretical research. The major setting is just one of the results of theoretical research. In the research, the forecast and systematical analysis for the development of technical skills in an industry should be done as a breakthrough according to practical requirements, so as to lay the solid foundation for students' innovation in their future job.

\section{IV.CONCLUSION}

It is known by above arguments and analyses that major setting plays a leading role to vocational education. As each major is set scientifically based on practical situations and development law of industries, the major setting is playing a vital role in the development of vocational education. This leading role is realized through summary, promotion and prospective discussion of vocational education as well as the breakthrough of innovation skills.

\section{REFERENCES}

[1] $\mathrm{Xu}$ Jian. Issues and countermeasures to major setting for the county-level vocational education[J]. Education Development Research, 2006, (10)

[2] Wang Jiaofan. Research on the Industry-University-Research Cooperation Talent Cultivation Mode in Higher Vocational Education [J]. Heilongjiang Institute of Science and Technology, 2011.

[3] Liu Wenbin. Major setting in higher vocational education based on sustainable development of personnel training-Taking an example of the major setting in Guangdong vocational colleges[J]. Higher Education Exploration, 2008 (3)

[4] Li Erchang. A brief analysis of major setting orientation of vocational education in minority areas[J]. Ethnic Education Study, 2010, 21(3)

[5] UNESCO.World Date on Education[M].International Bureau of Education,2004. 